«Keruen» scientific journal

M.O.Auezov Institute of Literature and Art

ISSN 2078-8134

Volume 2, Number 71 (2021)

https://doi.org/10.53871/2078-8134.2021.2-05

МРНТИ 17.01.17

\author{
А.К. Машакова \\ Институт литературы и искусства им. М.О.Ауэзова, \\ г. Алматы, Казахстан, e-mail: a_mashakova@mail.ru, \\ ORCID: 0000-0001-5700-457X
}

\title{
SOME SPECIFICS OF THE RECEPTION OF KAZAKH LITERATURE IN GERMANY
}

\begin{abstract}
In the article the author discusses the process of reception of Kazakh literature in Germany. Some features inherent in each stage of the development of the German reception of Kazakh literature are analyzed. For example, the descriptive and historical-cognitive nature of the perception of the first works of Kazakh writers, which were translated into German in the 1950s. The modern stage of the German reception is due to the predominance of in-depth analysis of the works of Kazakh authors. The names of modern participants in the process of German reception of Kazakh literature are presented. German researchers such as Leonard Kossuth, Sigrid Kleinmichel, Marcel Erdahl, Mark Kirchner, Friedrich Hitzer, Hans-Peter Durr and others are the active participants of the modern process of foreign reception of Kazakh literature. German professional readers analyze the artistic merits and style features of the works by Kazakh authors. They address the works of Kazakh authors with constant interest and evaluate them positively.
\end{abstract}

Key words: Kazakhstan, Germany, reception, literary relations, translation, articles, conferences

Introduction. For the international recognition of Kazakh literature, the perception of the works of Kazakh writers and poets abroad is of great value. When studying foreign reception of Kazakh literature, one should take into account the readers' professional approach to literary reception, their knowledge in relation to the foreign environment; one should rely on receptive sources, the authors of which are the writers, poets, literary critics, who are rightfully called professional readers. The current situation in Kazakhstan creates favorable opportunities for studying Kazakh literature in terms of foreign reception. The process of reception of Kazakh literature in Germany is of particular interest, since this country has a long-term interest in the Kazakh people. The first books in German which mention the Kazakhs appeared in the VIII century. At the same time, German travelers-scholars in Oriental studies began to visit the Kazakh lands. After the October Revolution, interest in the peoples of the Soviet Land, including the Kazakh people, increased. During the Soviet period, Kazakh-German literary relations developed especially actively, which was due to the publication of the works of many Kazakh writers and poets in the GDR. During the period of independence of Kazakhstan, friendly relations with Germany in the field of literature continue their development.

Methods. The methodological basis includes the works of foreign literary scholars such as R.J. Clements [1], S. Fish [2], H.R. Yauss [3], V.Iser [4], P.Toper [5], Yu.Borev [6], T.L.Selitrina [7], R.T.Gromyak [8]. The use of various methodological and theoretical approaches is assumed. The research is based on scientific concepts of the analysis of literary text and artistic national world. The used research methods include the following: objective-analytical, textological, heuristic-hermeneutic, historical-typological, comparative and psychological. The psychological approach to the literature is focused on the study of psychology of the author as a creator and on the study of perception, i.e. reception of the artistic work by the reader. This study was conducted 
based on the research works of the Kazakh scientists such as Sh.K. Satpayeva [9], N. Zh. Sagandykova [10], U.K. Kumisbayev [11], M.Kh. Madanova [12], A.K. Tusupova [13], whose works directly or indirectly reflect this issue. Attention is focused on the articles "Literary communication: the effects of cooperation between the reader and the narrator" [14], "Language as means of communication in the context of globalization" [15], "The integrative possibilities of fiction in the context of the humanities" [16], "Artistic communication and dialogue between cultures in transboundary conditions" [17], "Empathic reactions after reading: the role of genre, personality factors and affective reactions" [18], published in peer-reviewed scientific journals.

Results. The study of foreign reception of Kazakh literature enables the determination of periodization of this process. It can be divided into two stages: the first stage corresponds to the Soviet period of Kazakh literature development, and the second stage begins with Kazakhstan's independence and continues to the present day.

When considering the Soviet period, it should be noted that publication of Kazakh literature in German began in the 50s of the XX century. Among the publishing houses that published the works of Kazakh authors, the largest publishing house in the GDR, "Kultur und Fortschritt", should be noted. The first work published by this publishing house was Gabiden Mustafin's novel "Millionaire". Then a collection of Kazakh epics and fairy tales "Golden Yurt" was published. By the way, in the Scientific and Cultural Center "Auezov's House-Museum" one can get acquainted with the letters of Erich Müller and Mukhtar Auezov regarding the Kazakh folklore in connection with publication of this book. Later, the works of Takhavi Akhtanov and Mukhtar Auezov have been published. In 1964, this publishing house has merged with the publishing house "Volk und Welt", which continued to publish Kazakh literature. In this publishing house the books by many Kazakh authors such as Anuar Alimzhanov, Abish Kekilbayev, Satimzhan Sanbayev, Maurice Simashko, Olzhas Suleimenov, Dukenbai Doszhanov have been translated into German and published. The works of Kazakh writers Abdizhamil Nurpeissov and Takhavi Akhtanov were published by the Berlin publishing house "Aufbau". The children's publishing house "Kinderbuchverlag" published books by Tynymbay Nurmaganbetov, Marat Kabanbayev and Akseleu Seidimbekov.

The German publication of the novel "The Path of Abai" in the late 1950s aroused interest and a number of articles by German researchers such as Erich Müller, Herbert Krempien, Otto Braun, Werner Baum, who felt respect for Mukhtar Auezov and enthusiastically perceived his works.

Analyzing the process of German reception of Kazakh literature at this stage, several specific features can be distinguished. The first feature was that translations into foreign languages were done through the Russian language. The next reasonable feature of the reception of the works of Kazakh writers, translated into German in the 1950s, is the descriptive and historical-cognitive nature of this perception. Foreign reviews of these works have common desire to present to the reader not only the life and creative work of the author, but also the whole Kazakh nation, their customs, way of life, nature and other aspects of life. Quite naturally, at that time, the reception pursued more informational purposes, and enthusiastic reaction from foreign writers and literary critics prevailed. For example, German writer Alfred Kurella spoke about the novel by Mukhtar Auezov "The Path of Abai" as follows: "Have you read Abai yet? So you haven't read anything. This is incredible, this is amazing! The steppe becomes alive and fascinates with all the splendor of its pristine nature, its gestures and integral characters. And what passions - the Shakespearean! You feel the era like in no research work. And what a poetry! Not a single prose line in these two voluminous books, which are printed in a prose form" [19, 98].

In the 1960s, the world literary community was already familiar with Kazakh literature, there was no need to present it again, and so more attention was paid to specific works. In the responses of these years, the more deep analysis in relation to modern Kazakh novel is felt.

In the 1970s-80s, a further evolution of literary reception took place, there appeared serious and rather voluminous scientific articles on the originality of the creative writings of Kazakh authors. Thus, the articles by German writers Peter Kirchner and Sigrid Kleinmichel, which present 
an in-depth analysis of the works of Mukhtar Auezov, deserve attention. In 1975 the article "The versatility and richness of multinational literature" by P. Kirchner was published in Berlin in the magazine "Multinational Literature". In it, he considers the novel "The Path of Abai" as an example of socialist literary synthesis. It should be kept in mind that in those years socialist realism was the dominant method in literature of socialist countries. P. Kirchner analyzes the central images of the novel, and real people. The author of the article does not describe the life of the Kazakh people, their customs, and nature. P. Kirchner's attention is focused on the political situation in those years when Abai, being a mature man, met and became close to Russian political exiles, followers of Chernyshevsky and Dobrolyubov.

In 1982 in Berlin, the "Aufbau" publishing house prepared the collection "What Can a Writer Do on This Earth?". A substantial and voluminous article by German writer Z. Kleinmichel, dedicated to Mukhtar Auezov, was entitled "Between the Asian Middle Ages and Socialism". The author entitled it in such way, apparently because of the statement of Mukhtar Auezov: "I came from the Asian Middle Ages, which was more complex and backward than the European one. I have gone through three social formations and now I live at the beginning of the fourth" [20, 169], with which this article begins. The author of the article, Z. Kleinmichel, describes the life and creative path of the famous Kazakh writer, analyzing a number of his works, including "A Shooting at the Pass" and "The Fierce One". Z. Kleinmichel dwells in detail on the novel-dilogy "The Path of Abai". She tells how the process of creating this novel took place, how the author collected material about the main character - the poet Abai Kunanbayev, what difficulties arose on the way of Mukhtar Auezov. Sigrid Kleinmichel believes that only thanks to Mukhtar Auezov, Abai was recognized as a classic of Kazakh literature. In the conclusion of the article, she characterizes the creativity of the Kazakh writer in the following words: "the artistic, educational power of Mukhtar Auezov corresponds to all the social opportunities and demands of his time" [20, 188].

During this period, a new approach to the perception of Kazakh literature was felt, on the background of positive assessments and delightful epithets, there are also critical statements. So, in 1974, reviewing the creative writings of Abdizhamil Nurpeissov, Peter Kirchner and Gerlind Koenig in their article "Changes in the Life of the People" expressed the following critical remark: "The author succeeded in the first two parts of the trilogy much more than in the third part, to show the action motivated and convincing ... In the third part, the image power is insufficient when describing both the interventionists and the Russian revolutionaries. Nevertheless, the persuasive features of the novel as a whole are quite strongly expressed" [21]. And Leonard Kossuth, in the preface to O. Suleimenov's poetry collection "Along the Azimuth of Nomad Clans", which was published in the GDR in 1981, admits a certain difficulty in perceiving the works of the Kazakh poet Olzhas Suleimenov.

Foreign literary encyclopedias and reference books refer to the aspects of perception of the creativity of the Kazakh writers and poets in the world. In the second half of the XX century, the names of Abai Kunanbayev, Mukhtar Auezov, Zhambyl Zhabayev appeared in the famous German encyclopedias "Meyers Neues Lexikon" (Leipzig), "Meyers Enzyklopädisches Lexikon" (Mannheim), "Brockhaus Enzyklopädie" (Mannheim), "Lexikon Kröners der Weltliteratur" (Stuttgart), "Meyers Universal Lexikon" (Leipzig).

Discussion. In recent years, literary contacts between Kazakhstan and Germany have been developing quite fruitfully. During the period of Kazakhstan's independence, the strengthening of foreign literary reception is associated with marking the anniversaries of the classics of Kazakh literature at the international level under the auspices of UNESCO (United Nations Educational, Scientific and Cultural Organization): the 150th anniversary of Abai Kunanbayev in 1995, the 100th anniversary of Mukhtar Auezov in 1997 and 200th anniversary of Makhambet Utemissov in 2003. International conferences and colloquia were held abroad and in Kazakhstan.

German scientists Marcel Erdal and Mark Kirchner took part in the international conference in Almaty which was dedicated to the 150th anniversary of Abai. In their speeches, one common idea was expressed that at present the creative heritage of Abai is becoming the property of not only the Kazakh people, but also of all Turkic-speaking peoples. It is noteworthy that M. Erdal is the 
author of the researches on the Turkic languages, including the book "Formation of the ancient Turkic word. Functional approach to the lexicon". In 1995, M. Erdal and M. Kirchner were professors at the Goethe University in Frankfurt am Main. M. Kirchner is the author of the research work on the Kazakh language and dialects of the Kazakh Diaspora in Turkey and China. In Germany, his books "Phonology of the Kazakh language" and "Kazakh proverbs" were published. German scholars emphasize the versatility of Abai's poetry, who synthesized Eastern, Western and Kazakh cultures in his creativity.

Since the interest in Kazakh literature in Germany emerged in the Soviet era, one can also observe the continuity of reception. Thus, literary contacts which were established in those years continue to develop in the period of independence. The activities of the German literary critic, publisher, translator Leonard Kossuth serve as a striking example. He visited Kazakhstan many times, and is personally familiar with many Kazakh writers and poets, and is one of the best specialists in Kazakh literature in Germany. In 2003 he was awarded the Prize of the Kazakhstani representation of the International PEN-club for active propaganda and popularization of Kazakh literature in Germany. L. Kossuth publishes reviews and articles on the literature of Kazakhstan in German journals. In particular, in 2002 in the German magazine "Ossietzky" his article about Abdizhamil Nurpeissov's novel "The Last Duty" was published, and in 2003 the same journal published a review of the novel "The Wanderer's House" by Gerold Belger.

L. Kossuth takes an active part in all events related to Kazakh literature in Germany. In 2001, he attended the grand opening of Abai Street in Berlin. The famous German literary critic L. Kossuth wrote the following about this significant event: "Abai, after whom the street in Berlin is named, is sometimes called "The Kazakh Goethe". This metaphor has a ground, since it implies the meaning that this poet, composer and educator has for national literature, the universality of his creative writings and activity" $[22,43]$.

In December 2006, the evening "Pushkin and Abai meet in Berlin" was held at the House of Russian Culture and Science. Professor of the Leipzig University Roland Opitz presented his view of the creativity of A.S. Pushkin, and M. Kirchner, professor at the University of Giessen, spoke about Abai's poetry. He tried to convey to German listeners the great importance of Abai as the founder of Kazakh classical literature and a link between Kazakh and Western literature at the same time. The scientist emphasized the relevance and significance of Abai's edifications in the development of modern independent Kazakhstan and the formation of the Kazakh nation. At the end of his speech, M. Kirchner read his own translation of the poem "Autumn" into German.

The old friend of Kazakh literature L. Kossuth also spoke. It should be noted that at that time L. Kossuth had already completed the translation of twenty of Abai's poems into German, and some of them were performed by the author on that literary evening. The idea to start translating Abai came to L. Kossuth in 2003 during his visit to Almaty at the invitation of the Kazakh PEN Club. In the process of translating Abai's poems, L. Kossuth repeatedly asked for advice from the scholar in Abay studies G. Belger in Kazakhstan. As a result, in 2007 the book "Abay. Twenty Poems" was published in "Oenel" Publishing House in Cologne. It also includes the article by L. Kossuth "My path to Abai and translation issues", in which the author spoke about the process of translating Abai's poems into German. From this article you can find out how the German literary critic perceives the Kazakh poet, what impresses him and what he admires: "Twenty poems are a small number of the chosen ones, and yet, summing up, I would say: What a great poet speaks with these verses! How he thrills, writhing by his philosophical struggle to comprehend the irreconcilable and indissoluble opposition of mortality and immortality!" [23, 126].

The book "Abai. Zwanzig Gedichte" was published in Germany in the series "Kazakhstani Library". The publication of this series has been carried out since 2006 thanks to the efforts of Leonard Kossuth and with the assistance of the Embassy of Kazakhstan in Germany. The first work which was included into this series was the novel "The Last Duty" by A. Nurpeissov, published in 2006 in German. The translation was done by Annelore Nitschke, whom L. Kossuth attracted to this work as a brilliant translator. In the same year, Abish Kekilbayev's novel "The Minaret, or the End of a Legend" was published. At the presentations of these books in various German cities, L. 
Kossuth spoke about the creativity of Kazakh writers, with whom he has long been familiar and maintains friendly and business relations. Later, in the series "Kazakhstani Library", the novel "Dashing Time" by Mukhtar Auezov, the novels "Storm" by Takhavi Akhtanov and "House of the Wanderer" by Gerold Belger, poetry collections by Olzhas Suleimenov and Mukagali Makatayev were published.

Presenting the reception of Kazakh literature in Germany, it should be emphasized that an important factor in foreign literary reception is the creative contacts of the writers with foreign colleagues during international events and professional trips of literary figures abroad. The manifestation of these factors is observed in the process of foreign reception of A. Nurpeissov, O. Suleimenov, A. Kekilbayev and M. Shakhanov. So, the poetic works of M. Shakhanov, after being published in Kazakhstan, also quickly became known to German readers as a result of his foreign presentations of his books. In 1999, a presentation of M. Shakhanov's book "The Delusion of Civilization" in German took place in Germany. German literary figures Friedrich Hitzer, E. Pieper and Nobel Prize laureate Hans-Peter Duerr took part in the discussion. The well-known German writer and translator Friedrich Hitzer drew the readers' attention to the fact that the poem "The Delusion of Civilization" was highly appreciated by UNESCO as one of the achievements of modern world poetry.

Conclusion. The development of international literary relations is influenced by the following factors: literary translation, professional trips and personal contacts of writers, poets and literary critics, holding literary anniversaries at the world level. It is necessary to take into account the readers' professional approach to literary reception, their knowledge in relation to the foreign environment. On the example of German reception, it can be noted that the process of foreign reception of Kazakh literature is undergoing evolutionary development. At the initial stage, the descriptive nature of foreign publications on the creative writings of Kazakh poets and writers is a characteristic feature, and the modern stage is characterized by prevalence of in-depth analysis of the works of Kazakh authors. German professional readers analyze the artistic merit and stylistic features of the works of Kazakh authors. German researchers Leonard Kossuth, Sigrid Kleinmichel, Marcel Erdal, Mark Kirchner, Friedrich Hitzer, Hans-Peter Duerr and others are active participants of the modern process of foreign reception of Kazakh literature. They have constant interest in the creative writings of Kazakh authors and evaluate them positively.

This work was carried out in the frame of grant funding from the Science Committee of the Ministry of Education and Science of the Republic of Kazakhstan on the project AR08855803 "Kazakhstan and the world literary space: comparative studies" for 2020-2022.

\section{ГЕРМАНИЯДА КАЗАҚ ӘДЕБИЕТІН КАБЫЛДАУДЫН КЕЙБІР ЕРЕКШЕЛІКТЕРІ}

Андатпа. Мақалада Германиядағы қазақ әдебиетін қабылдау үдерісі қарастырылады. Қазақ әдебиетінің неміс рецепциясы дамуының әрбір кезеңіне тән кейбір ерекшеліктер талданады. Мысалы, 1950 жылдары неміс тіліне аударылған қазақ жазушыларының алғашқы шығармаларын қабылдаудың дескриптивтік және тарихи-танымдық сипаты қарастырылды. Неміс рецепциясының қазіргі кезеңі қазақ авторларының шығармаларын терең талдаудың басымдылығымен қамтамасыз етілген. Қазақ әдебиетінің немістік рецепциясы үдерісіне қатысушылардың есімдері ұсынылған. Неміс зерттеушілері Леонард Кошут, Зигрид Клейнмихель, Марсель Эрдаль, Марк Кирхнер, Фридрих Хитцер, Ханс-Петер Дюрр және басқалар қазақ әдебиетін шетелдік қабылдаудың заманауи үдерісінің белсенді қатысушылары болып табылады. Неміс кәсіби оқырмандары қазақ авторлары шығармаларының көркемдік құндылығы мен стильдік ерекшеліктерін талдайды. Олар қазақ авторларының туындыларына үнемі қызығушылықпен қарап, оң бағаларын беруде.

Түйін сөздер: Қазақстан, Германия, рецепция, әдеби байланыстар, аударма, мақалалар, конференциялар 


\title{
НЕКОТОРЫЕ ОСОБЕННОСТИ РЕЦЕПЦИИ КАЗАХСКОЙ ЛИТЕРАТУРЫ В ГЕРМАНИИ
}

\begin{abstract}
Аннотация. В статье рассматривается процесс рецепции казахской литературы в Германии. Проанализированы некоторые особенности, присущие каждому этапу развития немецкой рецепции казахской литературы. К примеру, дескриптивный и историкопознавательный характер восприятия первых произведений казахских писателей, переведенных на немецкий язык в 1950-е годы. Современный этап немецкой рецепции обусловлен преобладанием углубленного анализа произведений казахских авторов. Представлены имена современных участников процесса немецкой рецепции казахской литературы. Активными участниками современного процесса зарубежной рецепции казахской литературы являются немецкие исследователи Леонард Кошут, Зигрид Кляйнмихель, Марсель Эрдаль, Марк Кирхнер, Фридрих Хитцер, Ханс-Петер Дюрр и другие. Немецкие профессиональные читатели анализируют художественные достоинства и стилевые особенности произведений казахских авторов. Они относятся к творениям казахских авторов с постоянным интересом и положительно их оценивают.

Ключевые слова: Казахстан, Германия, рецепция, литературные связи, перевод, статьи, конференции
\end{abstract}

\section{REFERENCES}

1 Clements R.J. Comparative Literature as Academic Discipline. - New York: Modern Language Association of America, 1978. - 342 p. (eng.)

2 Fish, St. Literature in the Reader: Affective Stylistics // New Literary History. - Baltimore: Johns Hopkins University Press, 1970. - Vol. 2. - N 1. - P. 123-162 (eng.).

3 Jauss H.R. Toward an Aesthetic of Reception. - Minneapolis: University of Minnesota Press, 1982. - 231 p. (eng.)

4 Iser W. The Range of Interpretation. - New York: Columbia University Press, 2000. - 280 p. (eng.)

5 Topper P.M. Translation in the system of comparative literature. - Moscow: Nasledie, 2000. - 254 p. (rus.)

6 Borev Y. Interpretation of artistic work // Problems of modern comparative literature. - Moscow: Publ. House of the Institute of World Literature RAS, 2004. - P. 28-37 (rus.).

7 Selitrina T.L. Continuity of literary development and interaction of literatures. - Moscow: The higher school, 2009. - 288 p. (rus.).

8 Gromyak R.T. Methodology for the implementation of the receptive approach to literary phenomena in comparative studies // Literary Comparative. - 2005. - N 1. - P. 64-73 (ukr.).

9 Satpayeva Sh.K. Kazakh-European literary ties of the $19^{\text {th }}$ and the first half of the twentieth century // Classic studies. The connection of times and comparative literary studies. T. 4. - Almaty, 2012. - P. 16-195 (rus.).

10 Kumisbaev U.K. Kazakh poetry and the East. - Almaty: Kazak university, 1999. - 207 p. (rus.).

11 Madanova M.Kh. Introduction to comparative literature. - Almaty, 2003. - 252 p. (rus.).

12 Sagandykova N.J. Fundamentals of literary translation. - Almaty: Sanat, 1996. - 224 p. (rus.).

13 Tusupova A.K. Kazakh-Anglo-American literary relations. - Almaty: M.O.Auezov ILA, 2003. - 160 p. (rus.).

14 Dixon P., Bortolussi M. Literary communication: Effects of reader-narrator cooperation // Poetics (Scopus). - 1996. Vol. 23. - Issue 6. - P. 405-430 (eng.).

15 Kaimuldinova A., Begaliev N. Language as a means of communication in the context of globalization // News of NAS RK. - 2013. - N 4. - P. 126-130 (rus.).

16 Kardapoltseva V.N. Integrative Possibilities of Fiction Literature in the Context of the Humanitarian Disciplines // World of science, culture, education (Russian Science Citation Index). - 2015. - N 2. - P. 209-211 (rus.).

17 Gabdullina V.I., Dyusekenev D.N. Artistic Communication and Dialogue of Cultures in Transboundary Context // World of science, culture, education (Russian Science Citation Index). - 2018. - N 1. - P. 366-369 (rus.).

18 Koopman E.M. Empatic reactions after reading: The role of genre, personal factors and affective responses // Poetics (Scopus). - 2015. - Vol. 50. - P. 62-79 (eng.).

19 Kurella A. About the epic novel «The Way of Abai» // Kazakh literature in the evaluation of foreign criticism. - AlmaAta: Nauka, 1971. - P. 98-99 (rus.).

20 Kleinmichel Z. Between Asian Middle Ages and Socialism // What can a writer do on this earth? - Berlin: Aufbau, 1982. - P. 169-188 (germ.).

21 Kirchner P., Koenig G. Changes in the life of the people // Neue Deutsche Literatur. - 1974. - N 12. - P. 10-11 (germ.).

22 Kossuth L. The people and the world. Autobiographical evidence of a legendary publishing house. - Berlin: Nora, 2002. 379 p. (germ.)

23 Kossuth L. My path to Abai and translation problems // Abai. Twenty poems. - Berlin: Nora, 2019. - P. 115-131 (germ.).

\section{ӘДЕБИЕТ}


1 Клементс Р.Ж. (1978). Салыстырмалы әдебиет оқу пәні ретінде. - Нью-Йорк: Қазіргі американдық тіл қауымдастығы, 1978. - 342 б. (ағыл.).

2 Фиш Ст. (1970). Оқырман әдебиеті: Аффективті стиль // Жаңа әдебиет тарихи. - Балтимор: Джон Хопкинс универ. басп., 1970. - 2-т. - № 1. - Б. 123-162 (ағыл.). (ағыл.).

3 Яусс Х.-Р. Рецептивтік эстетика жолында. - Миннеаполис: Миннесота университетінің баспасы, 1982. - 231 б.

4 Изер В. (2000). Түсіндіру ауқымы. - Нью-Йорк: Колумбия универ. басп., 2000. - 280 б. (ағыл.).

5 Топер П.М. Салыстырмалы әдебиет жүйесіндегі аударма. - Мәскеу: Наследие, 2000. - 254 б. (орыс.).

6 Борев Ю. Көркем шығарманың интерпретациясы // Қазіргі салыстырмалы әдебиеттануының мәселелері. - Мәскеу: РҒА ӘӘИ басп., 2004. - Б. 28-37 (орыс.).

7 Селитрина Т. Әдеби дамудың сабақтастығы және әдебиеттердің өзара байланысы. - Мәскеу: Высшая школа, 2009. -288 б. (орыс.).

8 Громяк Р.Т. Салыстырмалы зерттеулерде әдеби құбылыстарға рецептивті көзқарасты жүзеге асыру әдістемесі // Әдеби салыстырмалы. - 2005. - № 1. - Б. 64-73 (укр.).

9 Сәтпаева Ш.Қ. XIX ғасыр мен XX ғасырдың бірінші жартысындағы қазақ-еуропалық әдеби қатынастар //

Классикалық зерттеулер. Уақыт байланысы мен салыстырмалы әдебиеттану. 4-т. - Алматы, 2012. - Б. 16-195 (орыс.)

10 Күмісбаев У.К. Қазақ поэзиясы және Шығыс. - Алматы: Қазақ университеті. 1999. - 207 б. (орыс.).

11 Маданова М.Х. Салыстырмалы әдебиеттануға кіріспе. - Алматы, 2003. - 252 б. (орыс.).

12 Сағандықова Н.Ж. Көркем аударма негіздері. - Алматы: Санат, 1996. - 224 с. (орыс.). (орыс.).

13 Түсіпова А.К. Қазақ-англо-американдық әдеби байланыстар. - Алматы: М.О.Ауезов ат. ӘӨИ, 2003. - 160 б.

14 Диксон П., Бортолучи М. Әдеби коммуникация: оқырманмен бірлесе жұмыс жасаудың әсері // Poetics (Scopus). 1996. - 23-т. - Шығ. 6. - Б. 405-430 (ағыл.).

15 Қаймулдинова А., Беғалиев Н. Тіл жаһандану жағдайындағы қарым-қатынас құралы ретінде // ҚР ҰҒА Хабарлары. - 2013. - № 4. - Б. 126-130 (орыс.).

16 Кардапольцева В.Н. Гуманитарлық ғылымдар контекстіндегі көркем әдебиеттің интегративті мүмкіндіктері // Ғылым, мәдениет, білім әлемі (РИНЦ). - 2015. - № 2. - Б. 209-211 (орыс.).

17 Габдуллина В.И., Дюсекенев Д.Н. Шекаралас ортадағы көркемдік қатынас және мәдениеттер диалогы: «қазақ мәтіні» имагологиялық зерттеу нысаны ретінде // Ғылым, мәдениет, білім әлемі (РИНЦ). - 2018. - № 1. - Б. $366-369$ (орыс.).

18 Купман Е.М. Окудан кейін эмпатикалық реакциялар: жанрдың рөлі, жеке факторлар және аффективті реакциялар // Poetics (Scopus). - 2015. - 50-т. - Б. 62-79 (ағыл.).

19 Курелла А. «Абай жолы» эпикалық романы туралы. Шетелдік сынды бағалаудағы қазақ әдебиеті. - Алма-Ата: Ғылым, 1971. - Б. 98-99 (орыс.).

20 Кляйнмихель 3. Орта ғасырлық Азия мен социализм арасында // Бұл жерде жазушы не істей алады? - Берлин: Ауфбау, 1982. - Б. 169-188 (нем.).

21 Кирхнер П., Кёниг Г. Халық өміріндегі өзгерістер // Neue Deutsche Literatur. - 1974. - № 12. - Б. 10-11 (нем.).

22 Кошут Л. Халық пен әлем. Аңызға айналған баспаның өмірбаяндық дәлелі. - Берлин: Нора, 2002. - 379 б. (нем.).

23 Кошут Л. Менің Абайға апаратын жолым және аударма мәселелері // Абай. Жиырма өлең. - Берлин: Нора, 2019. Б. $115-131$ (нем.).

\section{ЛИТЕРАТУРА}

1 Клементс Р.Ж. Сравнительная литература как академическая дисциплина. - Нью-Йорк: Ассоциация современного американского языка, 1978. - 342 с. (англ.).

2 Фиш Ст. Литература в читателе: Аффективная стилистика // Новая литературная история. - Балтимор: Изд. Университета Джона Хопкинса, 1970. - Т. 2. - № 1. - С. 123-162 (англ.). (англ.).

3 Яусс Х.-Р. На пути к рецептивной эстетике. - Миннеаполис: Изд-во Университета Миннесоты, 1982. - 231 с.

4 Изер В. Диапазон интерпретации. - Нью-Йорк: Изд. Колумбийского университета, 2000. - 280 с. (англ.).

5 Топер П.М. Перевод в системе сравнительного литературоведения. - Москва: Наследие, 2000. - 254 с. (рус.).

6 Борев Ю. Интерпретация художественного произведения // Проблемы современного сравнительного литературоведения. - Москва: Изд. ИМЛИ РАН, 2004. - С. 28-37 (рус.).

7 Селитрина Т. Преемственность литературного развития и взаимодействие литератур. - Москва: Высшая школа, 2009. -288 c. (pyc.).

8 Громяк Р.Т. Методика реализации рецептивного подхода до литературных явлений в компаративных исследованиях // Литературная компаративистика. - 2005. - № 1. - С. 64-73 (укр.).

9 Сатпаева Ш.К. Казахско-европейские литературные связи XIX и первой половины XX века // Классические исследования. Связь времен и сравнительное литературоведение. Т. 4. - Алматы, 2012. - С. 16-195 (рус.).

10 Кумисбаев У.К. Казахская поэзия и Восток. - Алматы: Каз.университет. 1999. - 207 с. (рус.).

11 Маданова М.Х. Введение в сравнительное литературоведение. - Алматы, 2003. - 252 с. (рус.).

12 Сагандыкова Н.Ж. Основы художественного перевода. - Алматы: Санат, 1996. - 224 б. (рус.).

13 Тусупова А.К. Казахско-англо-американские литературные связи. - Алматы: ИЛИ им. М.О.Ауэзова, 2003. - 160 c. (pyc.).

14 Диксон П., Бортолучи М. Литературное общение: эффекты сотрудничества читателя и рассказчика // Poetics (Scopus). - 1996. - Т. 23. - Вып. 6. - С. 405-430 (англ.).

15 Каймулдинова А., Бегалиев Н. Язык как средство коммуникации в условиях глобализации // Известия НАН РК. 2013. - № 4. - С. 126-130 (рус.)

16 Кардапольцева В.Н. Интегративные возможности художественной литературы в контексте гуманитарных дисциплин // Мир науки, культуры, образования (РИНЦ). - 2015. - № 2. - С. 209-211 (рус.) 
17 Габдуллина В.И., Дюсекенев Д.Н. Художественная коммуникация и диалог культур в условиях трансграничности: «казахский текст» как предмет имагологического исследования // Мир науки, культуры, образования (РИНЦ). - 2018. - № 1. - С. 366-369 (рус.).

18 Купман Е.М. Эмпатические реакции после прочтения: роль жанра, личностные факторы и аффективные реакции // Poetics (Scopus). - 2015. - Т. 50. - С. 62-79 (англ.).

19 Курелла А. О романе-эпопее «Путь Абая» // Казахская литература в оценке зарубежной критики. - Алма-Ата: Наука, 1971. - С. 98-99 (рус.).

20 Кляйнмихель 3. Между азиатским средневековьем и социализмом // Что может сделать писатель на этой земле? Берлин: Ауфбау, 1982. - С. 169-188 (нем.).

21 Кирхнер П., Кёниг Г. Перемены в жизни народа // Neue Deutsche Literatur. - 1974. - № 12. - С. 10-11 (нем.).

22 Кошут Л. Народ и мир. Автобиографические свидетельства о легендарном издательстве. - Берлин: Нора, 2002. 379 с. (нем.).

23 Кошут Л. Мой путь к Абаю и проблемы перевода // Абай. Двадцать стихотворений. - Берлин: Нора, 2019. - С. 115-131 (нем.). 